\title{
Pisatin Demethylase Genes Are on Dispensable Chromosomes While Genes for Pathogenicity on Carrot and Ripe Tomato Are on Other Chromosomes in Nectria haematococca
}

\author{
Deanna L. Funnell and Hans D. VanEtten \\ Department of Plant Pathology, University of Arizona, Tucson, AZ 85721.
}

Submitted 10 December 2001. Accepted 22 April 2002.

\begin{abstract}
Studies on the wide-host-range fungus Nectria haematococca MP VI have shown a linkage between virulence on pea and five of nine $P D A$ genes that encode the ability to detoxify the pea phytoalexin, pisatin. Most of the $P D A$ genes are on chromosomes of approximately 1.6 megabases $(\mathrm{Mb})$ and two of these genes, $P D A 1-2$ and $P D A 6-1$, have been demonstrated to reside on approximately 1.6-Mb chromosomes that can be lost during meiosis. Prior studies also have shown that the dispensable chromosome carrying PDA6-1 contains a gene (MAK1) necessary for maximum virulence on chickpea. The present study evaluated whether the other approximately 1.6-Mb chromosomes that carry $P D A$ genes also are dispensable, their relationship to each other, and whether they contain genes for pathogenicity on hosts other than pea or chickpea. DNA from the PDA1-1 chromosome (associated with virulence on pea) and the PDA6-1 chromosome (associated with virulence on chickpea) were used to probe blots of contour-clamped homogeneous electric field (CHEF) gels of isolates carrying different $P D A$ genes and genetically related $\mathrm{Pda}^{-}$isolates. All of the approximately 1.6-Mb PDA-bearing chromosomes hybridized with both probes, indicating that they share significant similarity. Genetically related $\mathrm{Pda}^{-}$ progeny lacked chromosomes of approximately $1.6 \mathrm{Mb}$ and there was no significant hybridization of any chromosomes to the PDA1-1 and PDA6-1 chromosome probes. When isolates carrying different $P D A$ genes and related $\mathrm{Pda}^{-}$isolates were tested for virulence on carrot and ripe tomato, there was no significant difference in lesion sizes produced by $\mathrm{Pda}^{+}$and $\mathrm{Pda}^{-}$isolates, indicating that genes for pathogenicity on these hosts are not on the $P D A$-containing chromosomes. These results support the hypothesis that the chromosomes carrying $P D A$ genes are dispensable and carry host-specific virulence genes while genes for pathogenicity on other hosts are carried on other chromosomes.
\end{abstract}

Additional keywords: CHEF analysis, Fusarium solani, maackiain, supernumerary chromosome.

The ascomycete Nectria haematococca Berk \& Broome mating population (MP) VI (anamorph Fusarium solani) is

Corresponding author: Hans D. VanEtten, Department of Plant Pathology, 104 Forbes, University of Arizona, Tucson 85721; Telephone: (520)-6219355; Fax: (520)-621-9290; E-mail: vanetten@ ag.arizona.edu

Current address of D. L. Funnell:: USDA-ARS, Wheat, Sorghum, and Forage Research, University of Nebraska, Lincoln 68583. pathogenic on several different plant species, but genetic analysis of virulence traits have been done only with respect to its pathogenicity on pea (Pisum sativum L.) and chickpea (Cicer arietinum L.). For maximum virulence on pea, it is required that this fungus be able to detoxify the pea phytoalexin pisatin (Wasmann and VanEtten 1996). The detoxification of pisatin (pisatin demethylating ability [Pda]) is carried out by pisatin demethylase, which is encoded by $P D A$ genes. Genetic studies have identified nine $P D A$ genes: PDA1-1, PDA1-2, PDA2, PDA3, PDA4, PDA5, PDA6-1, $P D A 6-2$, and $P D A 7$ (Funnell et al. in press; Kistler and VanEtten 1984a; Mackintosh et. al. 1989; Miao and VanEtten 1992a). All of these characterized PDA genes hybridize to the same DNA probe, indicating a high degree of sequence similarity (Funnell et al. in press; Maloney and VanEtten 1995; Miao et al. 1991b). However, only those PDA genes that confer a rapidly induced Pda activity (PDA1-1, PDA1-2, $P D A 4, P D A 5$, and $P D A 7)$ are linked to virulence on pea (George et al. 1998) (unpublished data).

Southern analysis of electrophoretic karyotypes (contourclamped homogeneous electric field [CHEF] analysis) has shown that all the PDA genes, except $P D A 5$ and $P D A 7$, are on relatively small chromosomes of similar size (approximately 1.6 Megabases [Mb]) (Funnell et al. in press; Miao et. al. 1991b). PDA5 and PDA7 were shown to be linked on relatively large but variably sized chromosomes of 4.6 to $5.7 \mathrm{Mb}$ or on separate chromosomes of 3.5 to $4.5 \mathrm{Mb}$ (Funnell et al. in press; Miao et. al. 1991b). Genetic analysis has indicated that PDA6-1 and PDA6-2 are allelic (Miao and VanEtten 1992a), but the interpretation of genetic tests of allelism among PDA genes has been difficult because of the meiotic instability of PDA-containing chromosomes (Kistler and VanEtten 1984a; Mackintosh et al. 1989; Miao et al. 1991a; Miao and VanEtten 1992a). PDA1-1 and PDA1-2 have been classified as allelic based on common restriction sites (Funnell et al. in press).

Of particular relevance to the present study is that some of the PDA genes are known to be on dispensable chromosomes. This was first shown with the chromosome carrying PDA6-1 but has subsequently been shown to be the case with the $P D A 1$-2-bearing chromosome and with at least a portion of the chromosomes that carry PDA5 and PDA7 (Funnell et al. in press; Miao et al. 1991a). One objective of the present study was to determine whether the approximately $1.6-\mathrm{Mb}$ chromosomes bearing the other PDA genes (PDA1-1, PDA4, and $P D A 6-1)$ are dispensable and whether the different approximately $1.6-\mathrm{Mb}, P D A$-bearing chromosomes share similarities other than the PDA genes. 
Previous studies also have shown that the PDA1-1-bearing chromosome contains a cluster of genes, called pea pathogenicity $(P E P)$ genes, needed for pathogenicity on pea and that PDA1-1 is within this cluster (Han et al. 2001; Kistler et al. 1996; VanEtten et al. 1998; Wasmann and VanEtten 1996). Studies of virulence determinants on chickpea among members of $N$. haematococca MPVI have shown that this fungus requires the ability to detoxify the phytoalexins medicarpin and maackiain for maximal pathogenicity on this host (Enkerli et al. 1998). One of the genes encoding this activity (MAK1) is located on the same $1.6-\mathrm{Mb}$ dispensable chromosome as PDA6-1 (Covert et al. 1996; Miao et al. 1992a). PDA6-1 is not linked to virulence on pea and, unlike the PDA1-1 chromosome, there is no evidence that additional chickpea virulence genes are linked to MAKl (Enkerli et al. 1998; VanEtten et al. 1998).

A second objective of the present study was to determine if the dispensable PDA chromosomes have genes for virulence on hosts other than pea or chickpea. The hosts used were ripe tomato fruit and mature carrot roots. $N$. haematococca or its anamorph (Fusarium solani) has been reported as a pathogen of both (Garg and Gupta 1979; Mandal and Dasgupta 1983).

\section{RESULTS}

To determine if a specific PDA gene was on a dispensable chromosome, it was necessary to identify the chromosome containing the particular gene. This was accomplished by hybridizing blots of $\mathrm{CHEF}$ gels with a $P D A$-specific probe $(S a c B)$. The electrophoretic karyotype of at least one $\mathrm{Pda}^{-}$ relative of each $\mathrm{Pda}^{+}$isolate involved in the genetic characterization of each gene also was analyzed visually for the presence of a chromosome of the approximate size of the PDAbearing chromosome in the $\mathrm{Pda}^{+}$isolate. Finally, $\mathrm{Pda}^{+}$isolates and their related $\mathrm{Pda}^{-}$progeny were assayed for the presence of DNA from the PDA chromosome by using the DNA from two different PDA-bearing chromosomes (PDA1-1 and PDA61) to probe blots of CHEF gels.

\section{Chromosomal locations of $P D A$ genes in field isolates that were the source of origin of a $P D A$ gene and in progeny containing a single $P D A$ gene.}

$P D A 1-1, P D A 2$, and $P D A 3$ were genetically characterized in a study that began with a cross between $\mathrm{T} 2$, an isolate obtained from infected pea, and T219, an isolate obtained from soil, (Table 1) (Kistler and VanEtten 1984a;). The three genes were unlinked and PDA1-1 and PDA2 were shown to have originated from $\mathrm{T} 2$, whereas $P D A 3$ was shown to have originated from T219 (Kistler and VanEtten 1984a). CHEF analysis of progeny containing a single $P D A$ gene demonstrated that the three genes are on chromosomes of $1.6 \mathrm{Mb}$ in each isolate (Fig. 1A and B: 77-13-7, 96-17, 62-22) (Miao et. al. 1991b). Only a single 1.6-Mb chromosomal band in $\mathrm{T} 2$ hybridized with SacB (Fig. 1A and B) (Miao et. al. 1991b); therefore, it was presumed that the PDA1-1 and PDA2 chromosomes comigrated in these gels. Modifications of CHEF conditions did not separate the two chromosomes in T2 (data not shown).

PDA4 and PDA6-1 were genetically characterized in crosses initiated with $\mathrm{T} 23$, a highly virulent isolate obtained from pea (Table 1), and T161, a field isolate of unknown origin that has low virulence on pea (Mackintosh et. al. 1989). The genes were unlinked and PDA4 was shown to originate from T23 and PDA6-1 from T161 (PDA6-1 was originally called PDA32 [Mackintosh et. al. 1989]). CHEF analysis of the progeny with a single $P D A$ gene showed that $P D A 4$ is on a $1.5-\mathrm{Mb}$ chromosome and $P D A 6-1$ is on a $1.6-\mathrm{Mb}$ chromosome (Fig. 1A and B: 196-10-7 [PDA4] and 156-30-6 [PDA6-1]) (Miao et. al. 1991a,b).

PDA6-2 was genetically characterized in a set of crosses that involved T-200, a field isolate from red clover with low virulence on pea, and a $\mathrm{Pda}^{-}$laboratory isolate. The $P D A$ gene in T200 was shown to be an allele of PDA6-1 (Miao and

Table 1. Description of pisatin demethylating ability $(\mathrm{Pda})^{+}$field isolates and $\mathrm{Pda}^{+}$and $\mathrm{Pda}^{-}$progeny used for analysis of chromosomal locations of $P D A$ genes and associated chromosomal DNA ${ }^{\mathrm{a}}$

\begin{tabular}{|c|c|c|c|c|}
\hline \multirow[b]{2}{*}{ Isolate } & \multirow[b]{2}{*}{$P D A$ genotype } & \multicolumn{2}{|c|}{ Lesions length $(\mathbf{m m})$} & \multirow[b]{2}{*}{ Source } \\
\hline & & $\mathbf{P e a}^{\mathbf{b}}$ & Chickpea $^{c}$ & \\
\hline \multicolumn{5}{|c|}{ Field isolates } \\
\hline $\mathrm{T} 2$ & $P D A 1-1, P D A 2^{\mathrm{d}}$ & $17.9 \pm 5.4(35)$ & 4.9 & VanEtten 1978 \\
\hline $\mathrm{T} 23$ & $P D A 4, P h d^{\text {efg }}$ & $19.8 \pm 6.6(42)$ & 3.6 & Fusarium Research Center (S101) \\
\hline T200 & $P D A 6-2^{\text {th }}$ & $4.8 \pm 1.4(16)$ & 10.3 & Fusarium Research Center (U2642) \\
\hline $\mathrm{T} 219$ & $P D A 3^{\mathrm{d}}$ & $4.4 \pm 1.7(15)$ & 3.7 & Fusarium Research Center (S544) \\
\hline \multicolumn{5}{|c|}{ Laboratory progeny } \\
\hline $44-100$ & None $^{\mathrm{i}}$ & $4.7 \pm 1.6(19)$ & $\ldots$ & Kistler and VanEtten 1984a \\
\hline $62-22$ & $P D A 3^{\mathrm{df}}$ & $4.7 \pm 1.5(15)$ & $\ldots$ & Kistler and VanEtten 1984a \\
\hline $77-13-7$ & $P D A 1-1^{\mathrm{d}}$ & $15.2 \pm 6.9(13)$ & $\ldots$ & Kistler and VanEtten 1984a \\
\hline $96-17$ & $P D A 2^{\mathrm{df}}$ & $5.6 \pm 1.5(7)$ & & Kistler and VanEtten 1984a \\
\hline $156-30-6$ & $P D A 6-1^{\text {th }}$ & $4.9 \pm 1.7(16)$ & $11.3^{\mathrm{j}}$ & Miao and VanEtten 1992a \\
\hline $179-1$ & None $^{\mathrm{i}}$ & $5.0 \pm 0.6(8)$ & $\ldots$ & Mackintosh et al. 1989 \\
\hline $179-5$ & None $^{\mathrm{i}}$ & $3.9 \pm 1.8(15)$ & $\ldots$ & Mackintosh et al. 1989 \\
\hline 196-10-7 & $P D A 4^{\mathrm{ef}}$ & $7.7 \pm 2.1(15)$ & $\ldots$ & Mackintosh et al. 1989 \\
\hline $241-21-4$ & None $^{f}$ & $4.7 \pm 1.8(16)$ & $2.0^{\mathrm{k}}$ & Miao and VanEtten 1992a \\
\hline $241-36-2$ & $P D A 6-2^{\mathrm{h}}$ & $4.7 \pm 1.8(16)$ & $4.2^{\mathrm{k}}$ & Miao and VanEtten 1992a \\
\hline
\end{tabular}

${ }^{\mathrm{a}}$ Additional isolates used to test virulence on pea, mature carrot roots and ripe tomato fruit are given in Tables 2 and 3.

${ }^{\mathrm{b}}$ Lesion lengths on pea measured six days following inoculation. Isolates were tested in two or more assays, except 96-17 and 179-1, which were tested in one. The number of individual plants used in calculating the mean lesions lengths are indicated in parenthesis.

${ }^{\mathrm{c}}$ Lesion lengths on chickpea were reported in Lucy et al. (1988) unless otherwise indicated.

d $P D A$ determined genetically by Kistler and VanEtten (1984a).

${ }^{\mathrm{e}} P D A$ determined genetically by Mackintosh and associates (1989).

${ }^{\mathrm{f}} P D A$ determined by Southern analysis by Miao and associates (1991b).

${ }^{\mathrm{g}} P h d=P D A$-hybridizing DNA genes, presumed to be nonfunctional PDA genes.

${ }^{\text {h }} P D A$ determined genetically by Miao and VanEtten (1992a).

${ }^{i} P D A$ determined by Southern analysis by this work.

${ }^{\mathrm{j}}$ Lesion lengths on chickpea were reported in Miao and VanEtten (1992b).

${ }^{\mathrm{k}}$ Lesion lengths on chickpea were reported by V. P. W. Miao and H. D. VanEtten (unpublished data). 
VanEtten 1992a). CHEF analysis of T200 and $\mathrm{Pda}^{+}$progeny showed that PDA6-2 is on a $1.7-\mathrm{Mb}$ chromosome (Fig. $1 \mathrm{~A}$ and B: T200) (Miao et. al. 1991b).

\section{Karyotypes of $\mathrm{Pda}^{-}$progeny used} in the characterization of the $P D A$ genes.

For the $\mathrm{CHEF}$ analysis of $\mathrm{Pda}^{-}$progeny from crosses involving $P D A 1-1, P D A 2$, and $P D A 3$, isolate 44-100, which lacks all three genes, was used (Table 1). Isolate $44-100$ is a random ascospore progeny from the initial cross between T2 (PDA1-1 and PDA2) and T219 (PDA3) (Kistler and VanEtten 1984a); therefore, there is no way to determine whether its $\mathrm{Pda}^{-}$phenotype resulted from the independent segregation of the three genes or the loss of $P D A$-containing chromosomes. For the analysis of progeny from crosses involving $P D A 4$, the $\mathrm{Pda}^{-}$ isolates $179-1$ and $179-5$ were selected (Table 1). They were random ascospore progeny from a cross between T23 (PDA4) and T161 (PDA6-1) (Mackintosh et. al. 1989) and, again, the absence of both genes could have resulted from independent segregation or loss of one or both chromosomes. For the analysis of crosses involving PDA6-2, the $\mathrm{Pda}^{-}$isolate 241-21-4 was selected (Table 1) because it was from a tetrad which exhibited loss of the $\mathrm{Pda}^{+}$phenotype (Miao and VanEtten 1992b). The parents of 241-21-4 were T200 (PDA6-2) and a $\mathrm{Pda}^{-}$isolate and all eight tetrad progeny were $\mathrm{Pda}^{-}$, indicating loss of the PDA6-2 gene.
CHEF analysis of these $\mathrm{Pda}^{-}$progeny showed that a chromosomal band of the size that carries the PDA gene in the $\mathrm{Pda}^{+}$field isolate parents and the $\mathrm{Pda}^{+}$progeny was absent in each of the $\mathrm{Pda}^{-}$progeny (Figure 1A and B: 44-100, 179-1, $179-5,241-21-4)$. The same phenomenon was previously observed in $\mathrm{Pda}^{-}$progeny of PDA6-1, PDA1-2, PDA5, and PDA7 (Funnell et al. in press; Miao et. al. 1991a), in which the loss of the $\mathrm{Pda}^{+}$phenotype was attributed to the loss of all or part of a chromosome containing the PDA genes. The current results suggest that the same phenomenon may have occurred in $\mathrm{Pda}^{-}$progeny from these other crosses, because chromosomes of the size containing PDA1-1, PDA2, PDA3, PDA4, or PDA6-2 were absent in these progeny.

\section{Hybridization of DNA from $P D A$-bearing chromosomes with chromosomes in $\mathrm{CHEF}$ gels of representative isolates carrying genetically characterized $P D A$ genes and Pda $^{-}$progeny.}

Hybridization of chromosomal probes to $\mathrm{Pda}^{+}$field isolates and $P d a^{+}$progeny. When DNA from the PDA1-1 or PDA6-1 chromosome was used to probe blots of CHEF gels, they hybridized with the chromosomes containing PDA1-1, PDA2, PDA3, PDA4, PDA6-1, and PDA6-2 (Fig. 1C and D). Under stringent conditions, there was no distinct and consistent hybridization with non $P D A$-hybridizing chromosomes in most of the karyotypes of $\mathrm{Pda}^{+}$isolates and progeny (Fig. 1C and D).
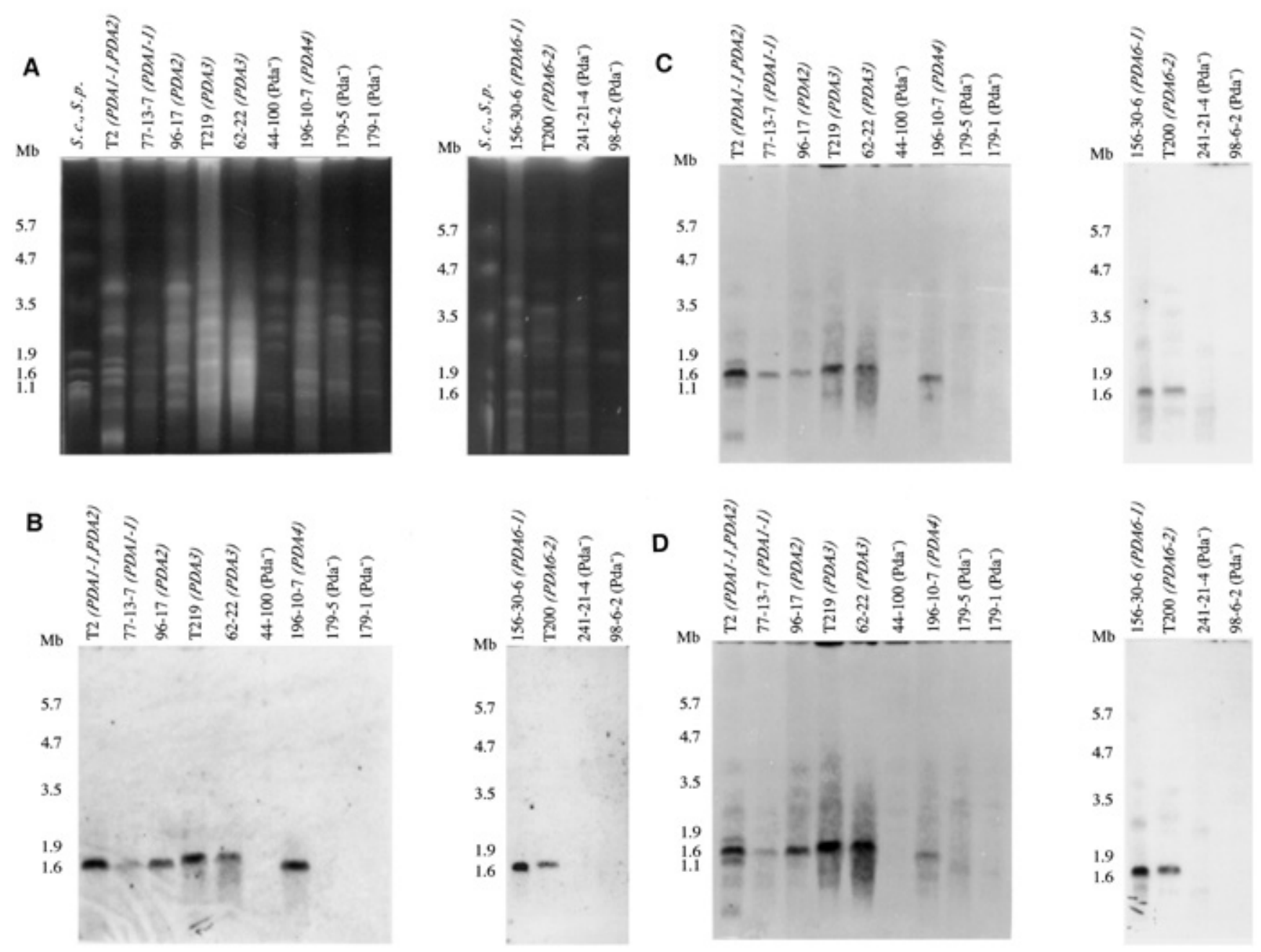

Fig. 1. CHEF analysis of pisatin demethylating ability $(\mathrm{Pda})^{+}$progenitor isolates, progeny carrying single $P D A$ genes, and $\mathrm{Pda}{ }^{-}$progeny using chromosomal DNA and SacB probes. A, CHEF gels. B, Blots of gels probed with SacB. C, Blots of gels probed with DNA from the PDA1-1 chromosome. D, Blots of gels probed with DNA from the PDA6-1 chromosome. 
Exceptions were two small chromosomes of T2 of approximately 1.8 and $1.3 \mathrm{Mb}$ which consistently hybridized with the chromosomal probes (Fig. 1A, C, and D), although to a lesser degree than the strongly hybridizing $1.6-\mathrm{Mb}$ band carrying the PDA1-1 or PDA2 genes. Hybridization with the $1.3-$ and $1.8-\mathrm{Mb}$ chromosomes of $\mathrm{T} 2$ was particularly intense when blots were probed with the PDA6-1 chromosome (Fig. 1D), which is known to contain repetitive sequences that hybridize with nonPDA-bearing chromosomes (Enkerli et al. 1998). In addition, a randomly cloned repetitive sequence from T2 (Nectria repetitive sequence [Nrs 1-2]) is known to hybridize with the 1.3-, 1.6-, and 1.8-Mb chromosomal bands of T2 (Kim et. al. 1995). The progeny of T2 used in this study (44-100, 62-22, 77-13-7, and 96-17) lacked the 1.3- and 1.8-Mb bands, and only the $1.6-\mathrm{Mb}$ PDA-bearing chromosomes of 77-13-7, 62-22, and 96-17 hybridized with the chromosomal probes. Therefore, the 1.3- and $1.8-\mathrm{Mb}$ chromosomes of $\mathrm{T} 2$ may be dispensable and were not inherited by the progeny of $\mathrm{T} 2$ used in this study.

Hybridization of chromosomal probes to the chromosomes of the Pda progeny used in the characterization of the PDA genes. Consistent with what had been observed with $\mathrm{Pda}^{-}$progeny from previous studies (Funnell et al. in press; Miao et. al. 1991a), no consistent hybridization of chromosomal probes with the chromosomes of $\mathrm{Pda}^{-}$isolates (44-100, 179-1, 179-5, and 241-21-4) was observed (Fig. 1C and D), showing that significant amounts of the DNA from the chromosomes containing PDA1-1, PDA2, and PDA3 (44-100), PDA4 (179-1 and 179-5), and $P D A 6-2$ (241-21-4) were absent in these progeny. Chromosomal probes did hybridize, presumably nonspecifically, with high concentrations of DNA, such as to unresolved DNA, DNA retained in wells, or degraded DNA at the bottoms of gels, in CHEF blots of both $\mathrm{Pda}^{+}$and $\mathrm{Pda}^{-}$isolates. However, this phenomenon was also occasionally observed when single-copy probes, such as $\mathrm{SacB}$, were used.

Cross-hybridization of PDA-bearing chromosomes. As indicated above, the PDA1-1 and PDA6-1 chromosomes cross-hy- bridized with one another (Fig. 1C: 156-30-1, T200; D: T2). In addition, when the PDA1-1 and PDA6-1 chromosomes were used to probe $\mathrm{CHEF}$ blots of isolates carrying $P D A 2, P D A 3$, $P D A 4$, and $P D A 6-1$, all of the $P D A$-bearing chromosome hybridized (Figure $1 \mathrm{C}$ and $\mathrm{D}$ ), indicating that these $P D A$-bearing chromosomes (from 1.5 to $1.7 \mathrm{Mb}$ in size) share significant similarity.

\section{Virulence on carrot and ripe tomato of isolates with and without $P D A$-bearing chromosomes.}

Representative MPVI field isolates and progeny carrying each $P D A$ gene, and $\mathrm{Pda}^{-}$progeny from each genetic background used in this study (Table 1), were tested for virulence on mature carrot roots and ripe tomato fruit. In addition to the isolates described previously, progeny used to genetically characterize $P D A 1-2, P D A 5$, and $P D A 7$ were included in the virulence study (Table 2). PDA1-2, PDA5, and PDA7 were characterized in a set of crosses between a field isolate from pea (T10) and an isolate from diseased mulberry branches (T7) (Funnell et al. in press). Southern analysis of DNA from progeny carrying only PDA1-2 showed that this PDA gene is similar to or homologous with PDA1-1 (Funnell et al. in press; Maloney and VanEtten 1994). $\mathrm{CHEF}$ analysis showed that $P D A 1-2$ is on a $1.5-\mathrm{Mb}$ chromosome and that $P D A 5$ and $P D A 7$ are on larger, variably sized (3.5 to $5.7 \mathrm{Mb}$ ) chromosomes (Funnell et al. in press). The PDA1-2 chromosome has been shown to hybridize with the PDAl-1 and PDA6-1 chromosomes (unpublished data) but not with the $P D A 5$ and PDA7 chromosomes (Funnell et al. in press). In addition to the MPVI isolates, an MPI isolate (T488), which is pathogenic on cucurbits (data not shown), was used as a control.

On carrot, inoculation with MPVI isolates normally resulted in collapsed tissue that was soft and brown, and the lesions tended to extend around the girth of the carrots (Fig. 2). On tomato, MPVI isolates normally made lesions that exhibited a circular collapsed area with splitting of the tissue, and mycelia visible in the cracks as previously shown (Wasmann and

Table 2. Virulence on carrot and ripe tomato of Nectria haematococca representative isolates carrying different PDA-bearing chromosomes and of closely related isolates lacking those chromosomes ${ }^{\mathrm{a}}$

\begin{tabular}{|c|c|c|c|c|c|}
\hline \multirow[b]{2}{*}{ Isolate $^{b}$} & \multirow[b]{2}{*}{$P D A$ chromosomes } & \multicolumn{2}{|c|}{ Tomato } & \multicolumn{2}{|c|}{ Carrot } \\
\hline & & Assay \#1 & Assay \#2 & Assay \#1 & Assay \#2 \\
\hline $\mathrm{T} 2$ & $P D A 1-1, P D A 2$ & $\ldots$ & $14.6 \pm 6.7(9)$ & $\ldots$ & $9.7 \pm 6.1(10)$ \\
\hline T219 & $P D A 3$ & $\ldots$ & $16.1 \pm 8.3(10)$ & $\ldots$ & $8.1 \pm 5.8(10)$ \\
\hline $77-13-7$ & PDA1-1 & $9.6 \pm 7.7(6)$ & $19.4 \pm 8.2(9)$ & $11.5 \pm 5.6(9)$ & $7.5 \pm 5.4(11)$ \\
\hline $96-17$ & PDA2 & $11.9 \pm 3.0$ & $\ldots$ & $3.6 \pm 3.0(9)^{* c}$ & $\ldots$ \\
\hline $62-22$ & PDA3 & $11.9 \pm 3.5(8)$ & $\ldots$ & $8.4 \pm 5.0(9)$ & $\ldots$ \\
\hline $44-100$ & None & $4.2 \pm 2.3(6)^{*}$ & $15.2 \pm 10.3(10)$ & $6.4 \pm 1.6(8)$ & $8.1 \pm 3.6(11)$ \\
\hline $\mathrm{T} 23$ & PDA4 & $16.9 \pm 4.3(7)$ & $\ldots$ & $10.3 \pm 4.8(8)$ & $\ldots$ \\
\hline $179-5$ & None & $11.0 \pm 3.6(6)$ & $\ldots$ & $6.5 \pm 4.2(10)$ & $\ldots$ \\
\hline $34-18$ & $P D A 1-2, P D A 5 / P D A 7$ & $15.8 \pm 3.6(6)$ & $14.6 \pm 5.8(9)^{\mathrm{d}}$ & $9.2 \pm 5.6(8)$ & $7.2 \pm 4.2(10)^{\mathrm{d}}$ \\
\hline $86-2-1$ & PDA5/PDA7 & $\ldots$ & $25.7 \pm 7.6(9)$ & & $10.6 \pm 4.1(11)$ \\
\hline $98-2-3$ & PDA5 & $17.4 \pm 4.7(7)$ & $\ldots$ & $12.7 \pm 5.2(9)$ & $\ldots$ \\
\hline $166-18-7$ & PDA5 & $\ldots$ & $17.5 \pm 5.6(9)^{\mathrm{d}}$ & & $7.9 \pm 4.0(10)^{\mathrm{d}}$ \\
\hline $98-6-2$ & None & $12.6 \pm 4.5(8)$ & $16.0 \pm 7.7(9)$ & $8.3 \pm 5.3(8)$ & $\ldots$ \\
\hline $156-30-6$ & PDA6-1 & $8.5 \pm 5.1(6)$ & $\ldots$ & $6.3 \pm 3.6(9)$ & $\ldots$ \\
\hline $241-36-2$ & PDA6-2 & $9.4 \pm 4.6(8)$ & $\ldots$ & $9.5 \pm 8.3(8)$ & $\ldots$ \\
\hline $241-21-4$ & None & $12.9 \pm 5.8$ & $\ldots$ & $8.4 \pm 5.3(8)$ & $\ldots$ \\
\hline $\mathrm{T} 488$ & $\ldots$ & $0.2 \pm 1.0(17)^{*}$ & $2.1 \pm 4.1(16)^{*}$ & $0.9 \pm 2.8(16)^{*}$ & $1.2 \pm 1.6(14)^{*}$ \\
\hline
\end{tabular}

${ }^{a}$ Tomato and carrot virulence assays were performed as described in text. Tomato and carrot assays \#1 were measured 5 days following inoculation and assays \#2 were measured 6 days following inoculations. The number in parentheses indicates the number of lesions measured for each isolate. Two measurements at right angles were made of each lesion. Due to variability between assays, means of isolates from different assays cannot be compared.

${ }^{\mathrm{b}}$ Isolates grouped together are from the same genetic studies. T488 is an $N$. haematococca MPI field isolate.

${ }^{\mathrm{c}}$ Mean lesion lengths marked with * are not significantly different from those of the negative control, T488, while those not marked are significantly different from those of T488 as determined by the Waller and Duncan pairwise tests. When the mean lesion lengths of pisatin demethylating ability (Pda) ${ }^{+}$ isolates considered as a group, or Pda ${ }^{-}$isolates considered as a group were compared with those of T488, the analysis was significant in assays \#1 and \#2 by the GLM procedure $(P \leq 0.05)$.

${ }^{\mathrm{d}}$ Ungerminated spores were used as inoculum. 
VanEtten 1996). In most cases, when tomato was inoculated with T488, there was no sign of infection. Occasionally, a slight depression, or rarely, a beige, hypersensitive-like response or a small, MPVI-like lesion resulted. Inoculation of carrots by T488 normally resulted in no reaction but, occasionally, there was a depression in the carrot that was not discolored and, in one case, a small MPVI-like lesion resulted.

Most MPVI isolates produced large lesions on tomato and carrot (Table 2). However, the relative sizes of the lesions produced by the different isolates varied and two isolates (96-17 on carrot and 44-100 in assay \#1 on tomato) only produced small lesions, which were not significantly different from those produced by T488. Thus, MPVI isolates can vary in their virulence on carrot and ripe tomato. In addition, isolates (e.g., 98-6-2) lacking a PDA-bearing chromosome can be highly virulent on both hosts (Table 2). When the mean lesion size of all isolates with $P D A$ chromosomes (i.e., $\mathrm{Pda}^{+}$isolates) versus the mean lesion size of all isolates lacking these chromosomes (i.e., $\mathrm{Pda}^{-}$isolates) were compared, there was no statistically significant difference between these two groups (Table 2). This indicates that the presence of a dispensable $P D A$-bearing chromosome in the genome of an isolate was not required for virulence on tomato or carrot.

We desired to examine further whether there were virulence genes that segregated independently from pea virulence genes carried on the dispensable PDA chromosomes. Therefore, we chose to assay virulence on tomato using more isolates without a $P D A$-bearing chromosome. We chose additional $\mathrm{Pda}^{-}$progeny from crosses $(44,75$, and 94$)$ used to characterize $P D A 1$ 1, $P D A 2$, and $P D A 3$, assuming that these $\mathrm{Pda}^{-}$isolates lack the $P D A$-bearing chromosomes as observed for other $\mathrm{Pda}^{-}$progeny from these crosses (Fig. 1). All the $\mathrm{Pda}^{-}$isolates were low in virulence on pea, as expected, when compared with $\mathrm{Pda}^{+}$ controls known to be highly virulent (77-13-7 and 34-18) or $\mathrm{Pda}^{-}$and $\mathrm{Pda}^{+}$controls known to be low in virulence (44-100, 166-18-7, and 166-22-1) on pea (Table 3). The five MPVI $\mathrm{Pda}^{-}$and $\mathrm{Pda}^{+}$control isolates had similar lesion sizes on tomato, and most of the $\mathrm{Pda}^{-}$progeny from crosses 44, 75, and 94 were similarly virulent on tomato (Table 3 ). However, two isolates, 75-7 and 94-8-3, were significantly less virulent than the other MPVI isolates tested and their mean lesion sizes were not significantly different than that of T488 (Table 3). When the assay was repeated with these two isolates and control isolates (Table 3; Fig. 2C), 75-7 and 94-8-3 both were significantly less virulent than the MPVI isolates 34-18, 77-13-7 $\left(\mathrm{Pda}^{+}\right), 44-100$, and 166-22-1 ( $\left.\mathrm{Pda}^{-}\right)$by the Waller and Duncan tests, and mean lesion size produced by 75-7 was not significantly different from that of T488 in both assays.

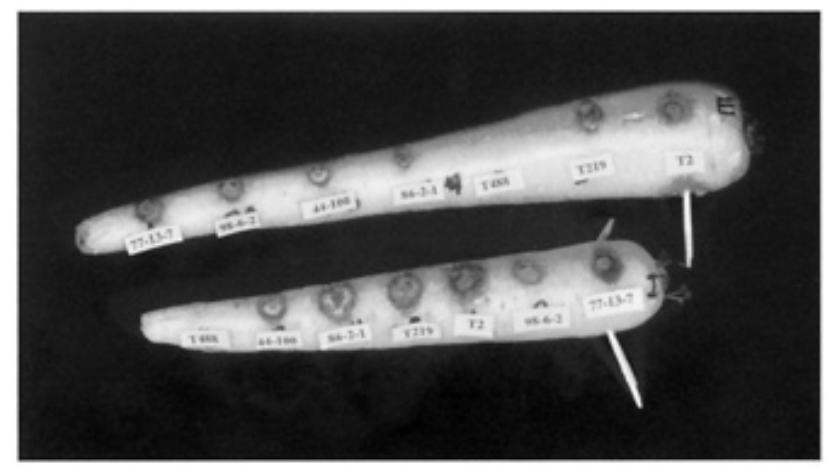

Fig. 2. Virulence assays on mature carrot roots. Lesions produced by MPVI isolates 77-13-7 (PDA1-1), 98-6-2 ( $\left.\mathrm{Pda}^{-}\right), 44-100\left(\mathrm{Pda}^{-}\right), 86-2-1$ (PDA5, PDA7), T219 (PDA3), and T2 (PDA1 and PDA2) and the negative control isolate (MPI), T488. Two carrots, with isolates inoculated in different positions, are shown.
To test whether 75-7 and 94-8-3 were affected in growth, the radial growth rates of these isolates were compared with those of their parents. The colony radii after 5 days were essentially the same for all isolates (21 to $23.5 \mathrm{~mm}$ ).

\section{DISCUSSION}

All the chromosomes carrying the genetically characterized $P D A$ genes, except for PDA5 and PDA7, have been shown to be of approximately $1.6 \mathrm{Mb}$ (Funnell et al. in press; Miao et. al. 1991b) (Fig. 1) and the present and prior studies indicate that all of these $P D A$-containing chromosomes are dispensable insofar as they are not required for growth in culture on minimal medium. That PDA-containing chromosomes could be dispensable was first and convincingly shown by Miao and associates (1991a) with the PDA6-1 chromosome. Crosses in which both parents contained $P D A 6-1$ yielded tetrads with $\mathrm{Pda}^{-}$progeny. $\mathrm{CHEF}$ analysis of such tetrads demonstrated that $\mathrm{Pda}^{-}$progeny lacked the PDA6-1-bearing chromosome and, when DNA from this chromosome was used as a probe, lacked significant hybridization to this chromosome elsewhere in their genomes (Miao et al. 1991a). Similar studies showed that PDA1-2 is also on a dispensable chromosome (Funnell et al. in press). For the present study, progeny from tetrads with aberrant tetrad ratios were available only for crosses involving PDA6-2. However, the absence of hybridization with the chromosomal probes to $\mathrm{CHEF}$ blots of the $\mathrm{Pda}^{-}$isolates used in characterizing PDA1-1, PDA2, $P D A 3$, and $P D A 4$ illustrate that most of the DNA contained on the $P D A$ chromosomes is absent in closely related $\mathrm{Pda}^{-}$isolates (Fig. 1A, C, and D).

It also is evident that all of the approximately 1.6-Mb $P D A$ chromosomes examined in this study share significant DNA homology (Fig. 1A, C, and D). Nevertheless, distinct differences between the PDA1-1 and PDA6-1 chromosomes are known. Genes on the two chromosomes confer different Pda phenotypes to isolates that contain them. Presence of the entire PDA1-1 chromosome is linked with virulence on pea, whereas the PDA6-1 chromosome is not: virulence on chickpea or tomato and carrot is not related to pathogenicity on pea (Kistler and VanEtten 1984b; Miao and VanEtten 1992b; V. P. W. Miao and H. D. VanEtten, unpublished data; this work). It is known that, in addition to $P D A 1-1$, the $P D A 1-1$-containing chromosome carries at least 3 transcribed $P E P$ genes that are involved in virulence on pea (Han et al. 2001). Alternatively, the PDA6-1 chromosome carries $M A K 1$, which is necessary for maximal virulence on chickpea (Covert et al. 1996; Enkerli et al. 1998); the PDAl1 chromosome lacks $M A K 1$ (E. Temporini and H. D. VanEtten, unpublished data). A repetitive element from the PDA6-1 chromosome (Nht2) does not hybridize with the PDA1-1-bearing chromosome (S. F. Covert, personal communication). This evidence indicates that, in spite of the cross hybridization of the two chromosomes, there are significant regions, including active genes, which are unique to each chromosome. However, not all of the approximately $1.6-\mathrm{Mb} P D A$-bearing chromosomes are highly similar. A $1.3-\mathrm{Mb}$ chromosome in field isolate T63 hybridizes with the $P D A$-specific probe $S a c \mathrm{~B}$, but the DNA from this chromosome does not hybridize with the PDA1-1 chromosome (Funnell et al. in press; unpublished data).

Although genes for virulence on pea (PDA and PEP) and chickpea $(M A K)$ can be found on dispensable PDA chromosomes, this does not appear to be the case for genes for virulence on ripe tomatoes or mature carrot roots. As previously demonstrated for the PDA1-1 chromosome (Wasmann and VanEtten 1996), none of the other small PDA-containing chromosomes are needed for high virulence on tomatoes (Fig. 2; Table 3). This also was shown to be true for pathogenicity on carrot (Fig. 2; Table 3). Preliminary data suggest that genes controlling the 
degree of virulence on tomato are present on the non $P D A$ containing chromosomes of $N$. haematococca (Table 3 ).

Recent analyses of the PDA1-1 chromosome are consistent with the suggestion that these chromosomes are of a different origin than the rest of the $N$. haematococca genome. The PEP region of the $P D A 1-1$ chromosome differs in codon usage and $\mathrm{GC}$ content from genes from the other chromosomes (Han et al. 2001). This suggests that the PEP genes, and possibly the entire chromosome, could have been obtained by horizontal transfer. In bacteria, the horizontal transfer of genes, in particular pathogenicity genes, appears to be a common event (Ochman et al. 2000). Whether it occurs regularly between fungi and, if so, how it occurs, is speculation. However, the transfer of DNA between mycoparasites and their fungal hosts (Wöstermeyer et al. 1997), as well as transfer of a supernumerary chromosome between vegetatively incompatible biotypes of Colletotrichum gleosporiodes (He et al. 1998), has been demonstrated. Conceptually, the $P D A$-containing dispensable chromosomes may be viewed as analogous to bacterial plasmids such as the Ti plasmid of Agrobacterium tumefaciens and the sym plasmids of Rhizobium spp. These plasmids contain a number of genes conditioning host plant associations. For both of these plasmids, "allelic variants" exist which determine host specificity (Hombrecher et al. 1984; Yanofsky et al. 1985). A parallel situation may exist with the different dispensable $P D A$ chromosomes of $N$. haematococca, in which there is substantial similarity between them but individual chromosomes may contain unique genes that condition host specificity. Clearly, more information is needed to know how the genes and other unique features of these chromosomes, such as repetitive elements and GC content, are related among the different $P D A$-bearing chromosomes, and how these chromosomes compare with the nondispensable regions of the genome.

\section{MATERIALS AND METHODS}

\section{Fungi.}

$N$. haematococca MPVI isolates used in this study were parents and progeny from crosses used to genetically characterize the nine PDA genes (Tables 1 and 2). PDA1-1, PDA2, and $P D A 3$ were characterized by Kistler and VanEtten (1984a), PDA4 and PDA6-1 (formerly known as PDA3-2) by Mackintosh and associates (1989), $P D A 6-1$ and $P D A 6-2$ by Miao and VanEtten (1992a), and PDA1-2, PDA5, and PDA7 by Funnell and associates (in press). In two cases ( $P D A 1-1$ and $P D A 2$; $P D A 5$ and $P D A 7$ ), the sources of the genes are field isolates that carry more than one gene. Each series of crosses was initiated with unrelated field isolates, except for the two series that characterized PDA6-1, which both involved field isolate, T161 (Mackintosh et. al. 1989; Miao and VanEtten 1992a).

Most isolates were retrieved from stocks of mycelium and spores maintained as previously described (VanEtten 1978). All isolates are members of MPVI except for T488, a field isolate pathogenic on cucurbits, belonging to $N$. haematococca MPI. Isolate numbers preceded by a "T" are field isolates. All other isolates are cross progeny.

\section{Preparation of chromosomal DNA and \\ pulsed field gel electrophoresis (CHEF).}

Preparation of chromosomal DNA and resolution of chromosomes from 1.1 to $6.0 \mathrm{Mb}$ in CHEF gels were as previously described (Funnell et al. in press).

\section{Southern analysis of CHEF gels.}

DNA in CHEF gels was transferred to membranes by standard protocols. A $1.35-\mathrm{kb}$ SstI fragment of the PDAT9 gene $(\mathrm{SacB})$ (Maloney and VanEtten 1994) was used as the PDA gene probe. DNA from the 1.6-Mb PDA1-1-bearing chromosome of isolate 77-13-7 and the 1.6-Mb PDA6-1-bearing chromosome from isolate 156-30-6 were extracted from CHEF gels of $0.7 \%$ low melting point (LMP) agarose (ultraPURE, BRL) per $0.5 \times$ TBE ( $1 \times$ TBE is $89 \mathrm{mM}$ Tris-borate, $\mathrm{pH} 8.3,25 \mathrm{mM}$ EDTA) as previously described (Funnell et al. in press). Labeling of DNA, hybridization, and washing of membranes were performed as previously described (Funnell et al. 2001, in press). Membranes were stripped by adding boiling $1 \%$ sodium dodecyl sulfate, cooling to room temperature, then rinsing with $1.5 \mathrm{M} \mathrm{NaCl} / 0.5$ M Tris, $\mathrm{pH} 7.5$.

\section{Virulence assays.}

Pea virulence assays were done using a "test tube assay" as previously described (Funnell et al. 2001) except that lesions were measured 6 days after inoculation.

Tomato and carrot virulence assays employed cv. Trust tomato (Eurofresh, Wilcox, AZ) and organically grown carrot (cv. Flame; Grimway Farms, Bakersfield, CA) purchased from a local supermarket (Reay's Ranch Market, Tucson, AZ). The tomatoes and carrots were washed with water, dried in a laminar-flow hood, sprayed twice with $95 \%$ ethanol, and allowed to dry. The epidermis of each tomato was pricked with a 25 -gauge needle, and a 4-mm-diameter agar plug from an inoculum plate was placed with the mycelial side against the wound. Carrots were inoculated without wounding. Except for two isolates in assay \#2 (see below), all inoculum was prepared by spreading a spore

Table 3. Virulence of Nectria. haematococca pisatin demethylating ability $(\mathrm{Pda})^{-}$isolates on pea and tomato

\begin{tabular}{|c|c|c|c|}
\hline \multirow[b]{2}{*}{ Isolate } & \multicolumn{3}{|c|}{ Lesion length $(\mathrm{mm})^{\mathrm{a}}$} \\
\hline & $\mathbf{P e a}^{\mathbf{b}}$ & Tomato assay \#3 & Tomato assay \#4 ${ }^{\mathrm{c}}$ \\
\hline \multicolumn{4}{|c|}{$\mathrm{Pda}^{-}$isolates } \\
\hline $44-36$ & $2.3 \pm 0.5(9)$ & $17.4 \pm 5.1(8)$ & $\ldots$ \\
\hline $44-46$ & $4.2 \pm 0.5(7)$ & $15.3 \pm 4.5(8)$ & $\ldots$ \\
\hline $44-64$ & $4.0 \pm 0.8(8)$ & $18.3 \pm 4.0(7)$ & $\ldots$ \\
\hline $75-7$ & $2.0 \pm 0.5(3)$ & $4.5 \pm 6.4(9)^{*}$ & $2.8 \pm 2.4(9)^{*}$ \\
\hline $94-1-3$ & $5.3 \pm 2.6(8)$ & $19.0 \pm 3.9(8)$ & $\ldots$ \\
\hline $94-2-1$ & $3.9 \pm 1.4(8)$ & $13.3 \pm 6.6(8)$ & $\ldots$ \\
\hline $94-3-3$ & $1.1 \pm 0.4(10)$ & $19.4 \pm 6.2(7)$ & $\ldots$ \\
\hline $94-4-5$ & $2.9 \pm 0.5(9)$ & $17.9 \pm 4.0(8)$ & $\ldots$ \\
\hline $94-5-3$ & $3.4 \pm 1.5(10)$ & $16.8 \pm 4.6(6)$ & $\ldots$ \\
\hline $94-6-1$ & $3.2 \pm 1.2(9)$ & $17.8 \pm 4.6(8)$ & $\ldots$ \\
\hline $94-7-4$ & $2.6 \pm 1.0(10)$ & $20.9 \pm 5.8(9)$ & $\cdots$ \\
\hline $94-8-3$ & $2.1 \pm 1.6(10)$ & $5.9 \pm 4.6(7)^{*}$ & $8.9 \pm 4.1(9)^{\mathrm{d}}$ \\
\hline \multicolumn{4}{|c|}{$\mathrm{Pda}^{+}$controls } \\
\hline $34-18$ & $16.3 \pm 7.9(9)$ & $22.7 \pm 6.5(8)$ & $23.0 \pm 4.1(9)$ \\
\hline $77-13-7$ & $16.4 \pm 6.2(5)$ & $15.2 \pm 8.4(7)$ & $22.1 \pm 4.3(9)$ \\
\hline $166-18-7$ & $4.7 \pm 2.1(8)$ & $23.0 \pm 5.3(8)$ & $\ldots$ \\
\hline \multicolumn{4}{|c|}{$\mathrm{Pda}^{-}$controls } \\
\hline $44-100$ & $2.2 \pm 0.9(5)$ & $17.8 \pm 4.6(9)$ & $19.5 \pm 5.7(10)$ \\
\hline $166-22-1$ & $5.1 \pm 1.3(8)^{\mathrm{e}}$ & $\ldots$ & $23.5 \pm 5.3(9)$ \\
\hline T488 & $\ldots$ & $1.7 \pm 2.5(25)^{*}$ & $1.0 \pm 1.8(11)^{*}$ \\
\hline
\end{tabular}

${ }^{\mathrm{a}}$ Mean lesion lengths marked with * were not significantly different from that of the negative control, T488, in the Waller and Duncan pairwise tests. Those not marked with asterisks are significantly different from that of T488 by both tests. For assay \#3, the mean lesions lengths of $\mathrm{Pda}^{+}$isolates considered as a group and those of $\mathrm{Pda}^{-}$isolates as a group were compared with that of T488 and the analysis was statistically significant by the GLM procedure $(P \leq 0.05)$.

${ }^{\mathrm{b}}$ Mean lesion lengths were from a single assay except for 166-22-1. Numbers in parentheses indicate the number of lesions measured.

${ }^{c}$ Assays were done as described in text. Lesions were measured 6 days following inoculation. Numbers in parenthesis indicate the number of lesions measured for each isolate.

d The mean lesion length of 94-8-3 in assay \#4 was statistically significant from those of $166-22-1,44-100,34-18$, and 77-13-7 by the Waller and Duncan pairwise tests.

e Virulence on pea determined in separate assay that included 34-18 and 166-18-7, which had mean lesion lengths of $20.8 \pm 8.1$ and $6.5 \pm 2.6$ $\mathrm{mm}$, respectively. 
suspension from a stock culture grown on Ustilago genetics minimal agar medium (M-100) (Stevens 1974) onto M-100 agar plates, which then were incubated for 2 days in the dark at $27^{\circ} \mathrm{C}$. For assay \#2, inoculum for two isolates (34-18 and 166-18-5) was prepared by spreading a suspension of conidia onto M-100 plates and immediately cutting agar plugs and inoculating tomatoes and carrots. Up to six isolates were inoculated onto each tomato and up to seven on each carrot. As a control, each tomato and carrot was inoculated with the MPI isolate T488, which is not reported to be pathogenic on carrot or tomato. From 8 to 11 replicates for each isolate were included in each experiment and isolates were assayed one to four times. A given isolate was inoculated only once on the same tomato and, at most, twice on the same carrot. The order of the inoculations was varied and, to counteract possible positional effects on carrots, each isolate was inoculated at least once at each of seven positions along the length of the carrot. Inoculated tomatoes and carrots were incubated at room temperature in autoclaved plastic (Sterilite) boxes ( 24.5 by 39 by $15 \mathrm{~cm}$ ). Wet paper towels were placed in the bottom of each box and tomatoes and carrots were placed on an autoclaved wire rack, constructed so to prevent contact with the bottom of the box. Lesions were measured 5 or 6 days after inoculation. Some of the lesions were not circular; therefore, two measurements at right angles were made of each lesion and both measurements were used in calculating the mean lesion size.

\section{Statistical analyses of tomato and carrot virulence assays.}

For statistical comparisons, isolates were grouped by the ability $\left(\mathrm{Pda}^{+}\right)$or inability $\left(\mathrm{Pda}^{-}\right)$to demethylate pisatin. Differences between these groups were tested using SAS procedure GLM (SAS Institute Inc., Cary, NC) both with and without T488 included as a group. Analysis of variance was also used to test for differences among isolates within groups. Mean lesion lengths of all the isolates were compared using both the Duncan and the Waller methods for multiple comparison of means (SAS procedure GLM).

\section{Radial growth bioassays.}

Radial growth measurements were done as previously described (Funnell et al. in press) except that 60-by-15-mm petri plates containing $8 \mathrm{ml}$ of peptone-glucose agar medium (Martin 1950) were employed. Growth was measured daily for 5 days.

\section{ACKNOWLEDGMENTS}

We thank T. Orum for statistical analyses of tomato and carrot virulence assays, D. Harvey and S. Jorgensen for assistance in the development of tomato and carrot assays, S. Jorgensen for technical assistance with assays, and C. Wasmann and E. Temporini for editorial comments. This work was supported in part by grants from the National Science Foundation, Division of Molecular and Cellular Biosciences (9905422) and the United States Department of Agriculture, National Research Initiative (99-35303-8681).

\section{LITERATURE CITED}

Covert, S. F., Enkerli, J., Miao, V. P. W., and VanEtten, H. D. 1996. A gene for maackiain detoxification from a dispensable chromosome of Nectria haematococca. Mol. Gen. Genet. 251:397-406.

Enkerli, J., Bhatt, G., and Covert, S. F. 1998. Maackiain detoxification contributes to the virulence of Nectria haematococca MPVI on chickpea. Mol. Plant-Microbe Interact. 11:317-326.

Funnell, D. L., Matthews, P. S., and VanEtten, H. D. 2001. Breeding for highly fertile isolates of Nectria haematococca MPVI that are highly virulent on pea and in planta selection for virulent recombinants. Phytopathology 91:92-101.

Funnell, D. L., Matthews, P. S., and VanEtten, H. D. In press. Identification of new pisatin demethylase genes (PDA5 and PDA7) in Nectria haematococca and non-Mendelian segregation of pisatin demethylating ability and virulence on pea due to loss of chromosomal elements. Fungal Gen. Biol.

Garg, P. K., and Gupta, M. N. 1979. A Fusarium rot of tomato fruits. Indian Phytopathol. 32:332-333.

George, H. L., Hirschi, K. D., and VanEtten, H. D. 1998. Biochemical properties of the products of the cytochrome P450 genes (PDA) encoding pisatin demethylase activity in Nectria haematococca. Arch. Microbiol. 170:147-154

Han, Y., Liu, X., Benny, U., Kistler, H. C., and VanEtten, H. 2001. Genes determining pathogenicity to pea are clustered on a supernumerary chromosome in the fungal pathogen, Nectria haematococca. Plant J. 25:305-314.

He, C., Rusu, A. G., Poplawski, A. M., Irwin, J. A. G., and Manners, J. M. 1998. Transfer of a supernumerary chromosome between vegetatively incompatible biotypes of the fungus Colletotrichum gleosporoides. Genetics 150:1459-1466.

Hombrecher, G., Gotz, R., Dibb, N. J. Downie, J. A., Johnston, A. W. B., and Brewin, N. J. 1984. Cloning and mutagenesis of nodulation genes from Rhizobium leguminosarum TOM, a strain with extended host range. Mol. Gen. Genet. 194:293-298.

Kim, H.-G., Meinhardt, L. W., Benny, U., and Kistler, H. C. 1995. NRS1, a middle repetitive sequence linked to pisatin demethylase genes in $\mathrm{Nec}$ tria haematococca. Mol. Plant-Microbe Interact. 8:524-531.

Kistler, H. C., Meinhardt, L. W., and Benny, U. 1996. Mutants of Nectria haematococca created by a site-directed chromosome breakage are greatly reduced in virulence toward pea. Mol. Plant-Microbe Interact. 9:804-809.

Kistler, H. C., and VanEtten, H. D. 1984a. Three non-allelic genes for pisatin demethylation in the fungus Nectria haematococca. J. Gen. Microbiol. 130:2595-2603.

Kistler, H. C., and VanEtten, H. D. 1984b. Regulation of pisatin demethylation in Nectria haematococca and its influence on pisatin tolerance and virulence. J. Gen. Microbiol. 130:2605-2613.

Lucy, M. C., Matthew, P. S., and VanEtten, H. D. 1988. Metabolic detoxification of the phytoalexins maackiain and medicarpin by Nectria haematococca field isolates: Relationship to virulence on chickpea. Phys. Mol. Plant Pathol. 33:187-199.

Mackintosh, S. F., Matthews, D. E., and VanEtten, H. D. 1989. Two additional genes for pisatin demethylation and their relationship to the pathogenicity of Nectria haematococca on pea. Mol. Plant-Microbe Interact. 4:341-349.

Maloney, A. P., and VanEtten, H. D. 1995. A gene from the fungal plant pathogen Nectria haematococca that encodes the phytoalexin-detoxifying enzyme pisatin demethylase defines a new cytochrome P450 family. Mol. Gen. Genet. 243:506-514.

Mandal, N. C., and Dasgupta, M. K. 1983. Postharvest diseases of perishables in West Bengal I: New host records and a new fungus in India. Indian J. Mycol. Plant Pathol. 1:73-76.

Martin, J. P. 1950. Use of acid, rose Bengal, and streptomycin in the plate method estimating soil fungi. Soil Sci. 69:215-232.

Miao, V. P. W., Covert, S. F., and VanEtten, H. D. 1991a. A fungal gene for antibiotic resistance on a dispensable ("B") chromosome. Science 254:1773-1776.

Miao, V. P. W., Matthews, D. E., and VanEtten, H. D. 1991b. Identification and chromosomal locations of a family of cytochrome P-450 genes for pisatin detoxification in the fungus Nectria haematococca. Mol. Gen. Genet. 226:214-223.

Miao, V. P. W., and VanEtten, H. D. 1992a. Three genes for metabolism of the phytoalexin maackiain in the plant pathogen Nectria haematococca: Meiotic instability and relationship to a new gene for pisatin demethylase. Appl. Environ. Microbiol. 58:801-808.

Miao, V. P. W., and VanEtten, H. D. 1992b. Genetic analysis of the role of phytoalexin detoxification in virulence of the fungus Nectria haematococca on chickpea (Cicer arietinum). Appl. Environ. Microbiol. 58:809-814.

Ochman, H., Lawrence, J. G., and Groisman, E. A. 2000. Lateral gene transfer and the nature of bacterial innovation. Nature 405:299-304.

Stevens, R. B. 1974. Page 703 in: Mycology Guidebook. University of Washington Press, Seattle, WA, U.S.A.

VanEtten, H. D. 1978. Identification of additional habitats of Nectria haematococca mating population VI. Phytopathology 68:1552-1556.

VanEtten, H., Jorgensen, S. Enkerli, J., and Covert, S. F. 1998. Inducing the loss of conditionally dispensable chromosomes during vegetative growth. Curr. Genet. 33:299-303.

Wasmann, C., and VanEtten, H. D. 1996. Transformation-mediated chromosome loss and disruption of a gene for pisatin demethylase decrease the virulence of Nectria haematococca on pea. Mol. Plant-Microbe Interact. 9:793-803.

Wöstermeyer, J., Wöstermeyer, A., and Voigt, K. 1997. Horizontal gene transfer in the rhizosphere: A curiosity or a driving force for evolution? Adv. Bot. Res. 24:399-429.

Yanofsky, M., Lowe, B., Montoya, A., Rubin, R., Krul, W., Gorgon, M., and Nester, E. 1985. Molecular and genetic analysis of factor controlling host range in Agrobacterium tumefaciens. Mol. Gen. Genet. 201:237-246. 